\title{
Um pensamento desafiante
}

Elizabeth Cancelli ${ }^{2}$

Há algumas semanas, estava parada naquela que considero a melhor livraria do Rio de Janeiro. Um lugar agradável, aconchegante. Folheando um e outro livro, não conseguia parar de pensar em várias das passagens deste Ideologia e contraideologia, de Alfredo Bosi.

Coloquei-me no lugar do artesão: que alegria ele deve ter tido nesta tessitura: madura, sincera, direta. Um mergulho naquilo que em determinado momento ele chama de exercício público de auto-análise, ao referir-se a Joaquim Nabuco. Ideologia e contraideologia é um texto em que o autor permite ao leitor um desvendar paulatino das ideias apresentadas, estabelecendo conexões com outras obras de Bosi, com sua trajetória acadêmica, com sua posição de homem público, enfim, com seu lugar na vida. Este é um livro que, de uma forma indireta, denuncia o lugar comum das vaidades acadêmicas e do conformismo político. Um livro de um homem sábio, maduro e singular para estes tempos de angústia e de pouca esperança, onde há pouco lugar para o ser e demasiado para o ter.

Ideologia e contraideologia é um trabalho que vai, lentamente, seduzindo o leitor. E seduz justamente porque não é letra morta. Seu autor aparece em cada linha, em cada conexão que realiza entre autores e ideias. Alfredo Bosi vai nos mostrando como se posicionou teórica e politicamente ao longo de sua vida intelectual. Conversa com Virgílio, com Vieira, Locke, Whitman, Voltaire e com tantos outros. Ao escrever, deixa o leitor imaginar, por exemplo, como estabelece relações com a poesia de Robert Lowell. Viaja pelo mundo das ideias e induz o leitor a fazer o mesmo: posiciona-se sobre elas e induz o leitor a posicionar-se. Bosi faz um imenso inventário.

É texto que, sem dúvida, tem alma. E o autor começa a nos desvendá-la a partir da leitura que faz das utopias; daquilo que reside justamente no gênero utópico: o exercício de crítica política e a incessante tarefa que nos cabe de entender e buscar o lugar de uma idealização primeira, ou seja, a de realizar a utopia pela projeção do sonho moderno, de um mundo voltado à idealização. Portanto, de um mundo que, ao final de contas, deve encontrar-se cercado de ideais e princípios.

2 Elizabeth Cancelli é professora livre-docente do Departamento de História da FFLCH/USP. 
Foi pensando assim, nessas várias possibilidades de leitura, que este livro de maturidade nos traz, que me veio a certeza de que no dia de hoje eu deveria dizer ao professor Alfredo Bosi o quanto me tocou a leitura deste volume. De como tive a pretensão de seguir seus fios contraideológicos, de entendê-lo como intelectual e como homem público. De como me senti, como cidadã, chamada e instigada a pensar com ele. No debate que travei com o autor, o professor Bosi me fez retomar à vida universitária que se guia pelas ideias, pelo humanismo, pela vida e não pelas carreiras, vaidades, aparências. Foi, portanto, gratificante, ao final da leitura, ter podido dizer que este é um trabalho tocante. Um texto de maturidade, de trajetória, que se expõe ao mundo. E devo observar o quão difícil é debatê-lo por ser multifacetado, não linear. Feito para muitas conversas, perguntas, observações, curiosidades.

Sua leitura, devo ainda dizer, vai se clareando aos poucos, na medida em que o leitor avança e entende como é a estratégia narrativa de Alfredo Bosi que, orientada na tensão entre ideologia e contraideologia, busca nelas a contraposição de valores morais e políticos. Anuncia, por isso, como Thomas More, uma espécie de visão capaz não só de pensar as possibilidades dos mundos que estavam e estão sendo descobertos, como dá um sentido de indagação à degeneração das tradições políticas que se afastaram da virtude cívica. Como em More, há um sentido de moral pública e de moral privada no trabalho do professor Bosi. Daí a indignação virtuosa e o equilíbrio que encontra nas análises que faz sobre os caminhos da humanidade e do Brasil, numa forma original de tentar achar o contexto de um mundo em busca da realização por meio do diálogo com os autores e com a História das ideologias e das contraideologias. Uma aposta, sem dúvida, que o professor Alfredo Bosi faz na trajetória do Homem em direção à humanização, como Ulisses na Odisseia.

Definitivamente, temos aqui, como ele mesmo enfatiza, ao longo de todo o livro, uma reflexão no que tange ao encontro da sabedoria ideal para a realização da virtude. Sua âncora: a contraideologia. O autor traz ainda, de forma velada, uma acirrada crítica às banalizadas visões tocquevillianas e weberianas de que a virtude estaria nos valores do espírito capitalista puritano em contraposição aos princípios do catolicismo, que teriam influenciado uma espécie de "frouxidão" latino-americana, como querem fazer crer muitos dos ditos pensadores do Brasil. É uma obra que, sem dúvida, reflete a gama dos debates intelectuais que marcaram e marcam o Brasil na sua contemporaneidade: um desafio. 